\title{
Exercise as a screening test for growth hormone deficiency in children
}

\author{
K. A. LACEY, A. HEWISON, and J. M. PARKIN \\ From the Royal Victoria Infirmary, Newcastle upon Tyne
}

\begin{abstract}
Lacey, K. A., Hewison, A., and Parkin, J. M. (1973). Archives of Disease in Childhood, 48, 508. Exercise as a screening test for growth hormone deficiency in children. The serum growth hormone response to exercise has been evaluated in 98 children with short stature. In 65 children growth hormone deficiency was excluded by a single postexercise level of more than $20 \mathrm{mIU} / \mathrm{ml}$. The test is simple and can be carried out as part of an outpatient consultation. It is recommended as an initial screening test for growth hormone deficiency in short children.
\end{abstract}

In normal subjects there is considerable variation in serum growth hormone levels during the day related to dietary intake and composition (Rabinowitz and Merimee, 1968), exercise (Buckler, 1969), stress (Helge, Weber, and Quabbe, 1969), and other factors. As levels may be low for much of the day (Greenwood, Hunter, and Marrian, 1964), random growth hormone estimations may fail to distinguish between normal and hypopituitary subjects. Thus, for evaluation of pituitary function it is necessary to measure the serum growth hormone after a stimulus for its release. The most effective stimulus is hypoglycaemia, and a firm diagnosis of growth hormone deficiency requires low growth hormone levels during an effective insulin tolerance test (Root, Bongiovanni, and Eberlein, 1971). This test is laborious and unpleasant and carries a risk. Since the majority of short children are not growth hormone deficient, it seems wise to use a screening test before this more complex procedure.

During exercise there is an increase in the level of serum growth hormone and this is associated with a rise in plasma nonesterified fatty acids (Hunter, Fonseka, and Passmore, 1965), the principal form in which fat is transported for use by muscle (Basu, Passmore, and Strong, 1960). It appears probable that growth hormone by its lipotropic action plays a part in supplying fuel for muscular exercise (Hunter et al., 1965).

Buckler (1972) has investigated the use of exercise as a screening test for growth hormone deficiency and has shown that the level of growth hormone in a single specimen taken 30 minutes after the onset of

Received 13 November 1972. exercise exceeded $10 \mathrm{mIU} / \mathrm{ml}$ in $90 \%$ of normal subjects. The subjects in his study were aged from 8 to 48 years, only a small proportion being children. In this paper we present an assessment of the value of exercise stimulation as a screening test for growth hormone deficiency in a large series of short children.

\section{Material and methods}

The study population was comprised of 98 children whose heights were below the third centile (Tanner, Whitehouse, and Takaishi, 1966). 79 of these children were assessed in a survey of all children born in Newcastle upon Tyne in 1960 whose heights, at the age of 10 or 11 years, were below the third centile. The remaining 19 children were referred to a growth clinic.

The exercise was carried out using an exercise bicycle (The Oscar, Ayleys Products, Cornwall) fitted with a friction wheel which could be tightened to vary the resistance to pedalling. Each child pedalled the bicycle for 10 minutes, the resistance being increased as far as the child could reasonably tolerate. Most children became breathless but not distressed or exhausted. A blood sample for serum growth hormone estimation was taken from all children 30 minutes after the onset of the exercise and from 42 children immediately before the start of the exercise. The test was carried out during an ordinary outpatient consultation and the children were not prepared in any particular way. Hypothyroidism, chronic renal disease, and ovarian dysgenesis were excluded in all children and all had a skeletal age estimation (Tanner, Whitehouse and Healy, 1962). In some children pituitary function was also assessed using Bovril (Jackson, Grant, and Clayton, 1968), insulin (Raiti, 1971), or glucose (Hunter et al., 1967) stimulation.

Serum growth hormone was estimated by a double antibody radioimmunoassay (Hartog et al., 1964) using 
the MRC standard A. The standard used was compared with a sample of the 1st International Reference Preparation for Immunoassay (1st IRP) and was shown to be of the same potency; the results, therefore, are expressed as $\mathrm{mIU} / \mathrm{ml}$.

\section{Results}

\section{Survey children.}

Postexercise levels of serum growth hormone. The distribution of postexercise levels in the 79 survey children is shown in Fig. 1. In 54 children (68\%) the postexercise level exceeded $20 \mathrm{mIU} / \mathrm{ml}$, the level suggested as the criterion for the exclusion of growth hormone deficiency (Tanner et al., 1971). Of the remaining 25 children, whose levels were less than $20 \mathrm{mIU} / \mathrm{ml}$, growth hormone deficiency was considered unlikely in 19 on clinical grounds. The heights of 8 of these were above the third centile

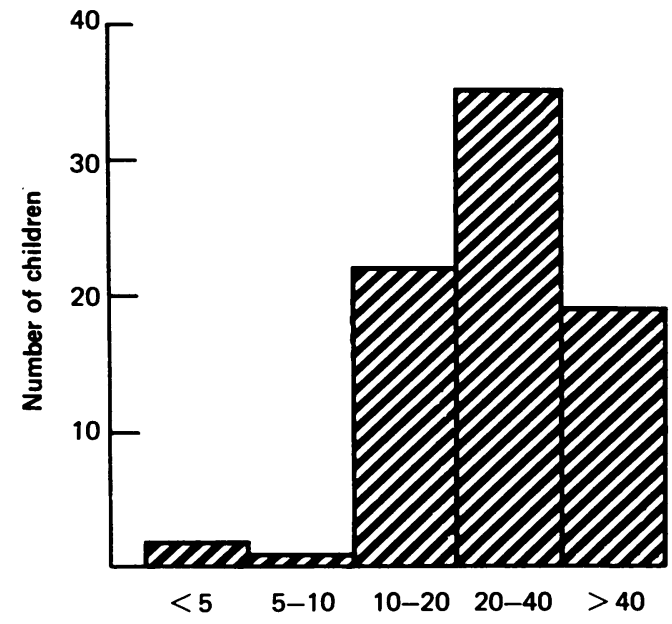

Postexercise serum growth hormone levels in $\mathrm{m} \mathrm{I} \mathrm{U} \mathrm{/mI}$

FIG. 1.-Distribution of postexercise serum growth hormone levels in 79 survey children.

when allowance was made for midparental height (Tanner, Goldstein, and Whitehouse, 1970), and the diagnosis of familial short stature was supported by the fact that their skeletal ages were retarded by less than one year. 7 children had growth rates exceeding $5 \mathrm{~cm} /$ year from the age of 5 years and the remaining 4 children had heights that were just below the third centile and skeletal ages retarded by less than one year. The postexercise serum growth hormone levels in all 19 children were between 10 and $20 \mathrm{mIU} / \mathrm{ml}$.

The 2 children with postexercise levels of less than $5 \mathrm{mIJ} / \mathrm{ml}$ may both be examples of suppression of growth hormone secretion associated with emotional deprivation (Powell et al., 1967). In both the test was carried out shortly after their removal from home because of parental neglect. One had a Bovril stimulation test 1 month later and the other a glucose stimulation test after an interval of 9 months, and on the second occasion the serum growth hormone levels in both were greater than 50 $\mathrm{mIU} / \mathrm{ml}$.

There remain 4 children in whom partial growth hormone deficiency cannot be excluded on clinical grounds; their heights remained below the third centile when allowance was made for midparental height, their growth rates were less than $5 \mathrm{~cm} /$ year from the age of 5 years, and their skeletal ages were retarded by more than 6 months. Postexercise levels of growth hormone of 3 were between 10 and $20 \mathrm{mIU} / \mathrm{ml}$, and in 1 the level was $8.9 \mathrm{mIU} / \mathrm{ml}$ after exercise and less than $5 \mathrm{mIU} / \mathrm{ml}$ after Bovril.

Growth hormone increments. The pre-exercise levels in 42 children are shown in Fig. 2 . In 7 they were greater than $20 \mathrm{mIU} / \mathrm{ml}$, and only in this small group could growth hormone deficiency have been excluded on the basis of this single random estimation. In 4 of these children the postexercise level was lower than the pre-exercise value. In 23 out of 38 children the serum growth hormone rose

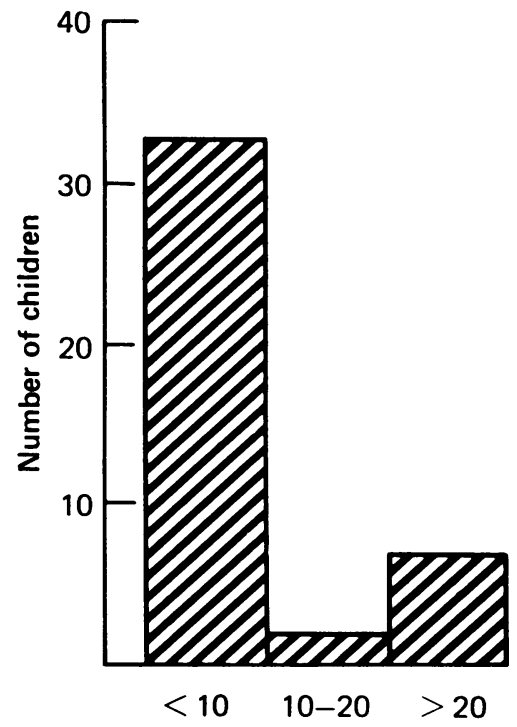

Pre-exercise serum growth hormone levels in $\mathrm{m} \mathrm{I} \mathrm{U} / \mathrm{ml}$

FIG. 2.-Distribution of pre-exercise serum growth hormone levels in 42 survey children. 
from below to above $20 \mathrm{mIU} / \mathrm{ml}$ after exercise, thereby excluding a diagnosis of growth hormone deficiency, and in a further 10 children the value increased from below to above $10 \mathrm{mIU} / \mathrm{ml}$. Of the remaining 5, 3 had pre-exercise levels greater than $20 \mathrm{mIU} / \mathrm{ml}$, while in 2 the levels both before and after exercise were less than $10 \mathrm{mIU} / \mathrm{ml}$.

Growth clinic patients. In 19 short children referred to a growth clinic, exercise was the initial screening test for growth hormone deficiency. The results are shown in Table I together with the peak levels after insulin or Bovril stimulation when these were done.

Two children (Cases 3 and 4) with growth hormone deficiency gave consistent results with all stimuli. Consistent results also were obtained in 1 child (Case 6) thought to be stunted for psychosocial reasons. 2 children gave disparate results. Case 5 produced normal growth hormone levels after Bovril, but just failed to do so after exercise. Case 7 failed to respond to both Bovril and exercise, but responded normally to insulin. Growth hormone deficiency was excluded in 9 children using the exercise test during the initial outpatient consultation.

\section{Discussion}

The lower limit of the normal serum growth hormone level after stimulation is not exactly defined, and the use of different standards for assay makes comparison between published series difficult. Kaplan et al. (1968), using a Wilhelmi growth hormone preparation as standard, suggested that a level of $7 \mathrm{ng} / \mathrm{ml}$ or more after stimulation probably indicates normal function. Frohman, Aceto, and MacGillivray (1967), also using a Wilhelmi standard, considered a post-stimulation level of $9 \mathrm{ng} / \mathrm{ml}$ to be the critical level. The potency of the Wilhelmi standard is approximately twice that of the 1st IRP, and so the equivalent lower limits of normal would be 14 and $18 \mathrm{mIU} / \mathrm{ml}$, respectively. Stimmler and Brown (1967), drawing from the experience of workers investigating the normal response in adults (Roth et al., 1963), suggested $10 \mathrm{ng} / \mathrm{ml}$ as the lower limit of normal, though in 4 of their cases not considered to be hypopituitary on clinical grounds the peak level after insulin stimulation was less than this. The most stringent criterion for normality has been taken by Tanner et al. (1971) who considered 20 $\mathrm{mIU} / \mathrm{ml}$ as the lower limit of the normal response, and suggested that peak growth hormone levels between 7 and $20 \mathrm{mIU} / \mathrm{ml}$ indicates partial growth hormone deficiency when the height velocity is consistent with this diagnosis. There may be considerable overlap in peak values between normal children and those with partial growth hormone deficiency, and the basic question of whether a lack of growth hormone is the limiting factor in a child's growth may only be answered by a therapeutic trial of growth hormone.

The exercise test has real practical advantages over most other stimulation tests. It is easily

TABLE I

Maximum serum growth hormone levels after different stimuli in 19 short children referred to a growth clinic

\begin{tabular}{|c|c|c|c|c|}
\hline \multirow{2}{*}{$\begin{array}{l}\text { Case } \\
\text { no. }\end{array}$} & \multicolumn{3}{|c|}{$\begin{array}{l}\text { Maximum post-stimulation serum } \\
\text { growth hormone level (mIU/ml) }\end{array}$} & Diagnosis \\
\hline & Exercise & Bovril & Insulin & \multirow[b]{2}{*}{$\begin{array}{l}\text { ? Constitutional delayed growth } \\
\text { Turner's syndrome } \\
\text { Growth hormone deficiency } \\
\text { Growth hormone deficiency } \\
\text { Low birthweight } \\
\text { Psychosocial short stature } \\
\text { Constitutional delayed growth } \\
\text { Constitutional delayed growth } \\
\text { Low birthweight } \\
\text { Stunting due to steroids } \\
\text { Familial short stature } \\
\text { Constitutional delayed growth } \\
\text { Low birthweight } \\
\text { Constitutional delayed growth } \\
\text { Constitutional delayed growth } \\
\text { Constitutional delayed growth } \\
\text { Constitutional delayed growth } \\
\text { Uncertain ? familial } \\
\text { Psychosocial short stature }\end{array}$} \\
\hline $\begin{array}{r}1 \\
2 \\
3 \\
4 \\
5 \\
6 \\
7 \\
8 \\
9 \\
10 \\
11 \\
12 \\
13 \\
14 \\
15 \\
16 \\
17 \\
18 \\
19\end{array}$ & $\begin{array}{r}15 \cdot 0 \\
4 \cdot 0 \\
1 \cdot 5 \\
4 \cdot 3 \\
18 \cdot 0 \\
5 \cdot 0 \\
8 \cdot 0 \\
22 \cdot 0 \\
24 \cdot 0 \\
21 \cdot 0 \\
50 \cdot 0 \\
10 \cdot 0 \\
50 \cdot 0 \\
14 \cdot 0 \\
35 \cdot 0 \\
43 \cdot 0 \\
22 \cdot 0 \\
82 \cdot 0 \\
9 \cdot 5\end{array}$ & $\begin{array}{r}2 \cdot 5 \\
2 \cdot 8 \\
5 \cdot 0 \\
1 \cdot 7 \\
28 \cdot 0 \\
8 \cdot 0 \\
8 \cdot 4\end{array}$ & $\begin{array}{l}5 \cdot 3 \\
2 \cdot 1 \\
8 \cdot 0 \\
50\end{array}$ & \\
\hline
\end{tabular}


Exercise as a screening test for growth hormone deficiency in children

TABLE II

Comparison of different methods of stimulation of growth hormone release

\begin{tabular}{|c|c|c|c|c|c|c|c|c|}
\hline \multirow{3}{*}{ Study } & \multirow{3}{*}{$\begin{array}{l}\text { Method of } \\
\text { stimulation }\end{array}$} & \multirow{3}{*}{$\begin{array}{l}\text { No. of } \\
\text { children }\end{array}$} & \multirow{2}{*}{\multicolumn{4}{|c|}{$\frac{\text { Percentage of children }}{\text { Maximum GH (mIU/ml) }}$}} & \multirow{3}{*}{$\begin{array}{l}\text { Mean maximum } \\
\mathrm{GH}(\mathrm{mIU} / \mathrm{ml})\end{array}$} & \multirow{3}{*}{ Age (yr) } \\
\hline & & & & & & & & \\
\hline & & & $<5$ & $5-10$ & $10-20$ & $>20$ & & \\
\hline $\begin{array}{l}\text { Grant et al. (1970) } \\
\text { Root et al. (1967) } \\
\text { Kaplan et al. (1968) } \\
\text { Frohman et al. (1967) } \\
\text { Frasier, Hilburn, and Matthews (1967) } \\
\text { Underwood et al. (1971) } \\
\text { Buckler (1972) } \\
\text { Present study }\end{array}$ & $\begin{array}{l}\text { Bovril } \\
\text { Insulin } \\
\text { Insulin } \\
\text { Insulin } \\
\text { Arginine } \\
\text { Insulin } \\
\text { Sleep } \\
\text { Insulin } \\
\text { Exercise } \\
\text { Exercise }\end{array}$ & $\begin{array}{l}32 \\
10 \\
10 \\
11 \\
11 \\
10 \\
14 \\
12 \\
17 \\
69\end{array}$ & $\begin{array}{r}0 \\
0 \\
0 \\
9 \\
18 \\
0 \\
0 \\
8 \\
0 \\
0\end{array}$ & $\begin{array}{r}0 \\
10 \\
20 \\
9 \\
9 \\
0 \\
7 \\
25 \\
18 \\
0\end{array}$ & $\begin{array}{l}18 \\
50 \\
10 \\
18 \\
27 \\
20 \\
50 \\
25 \\
18 \\
28\end{array}$ & $\begin{array}{l}82 \\
40 \\
70 \\
64 \\
46 \\
80 \\
43 \\
42 \\
64 \\
72\end{array}$ & $\begin{array}{l}22 \cdot 4 \\
24 \cdot 6 \\
36 \\
23 \\
19 \cdot 3 \\
20 \cdot 4 \\
18 \cdot 5 \\
24 \cdot 5 \\
29\end{array}$ & $\begin{array}{l}3-18 \cdot 5 \\
11 \cdot 5 \pm 2 \cdot 4 \\
6 \cdot 7 \\
\\
8 \cdot 2 \pm 2 \cdot 9 \\
10 \cdot 0 \pm 2 \cdot 5 \\
10 \cdot 0 \pm 2 \cdot 5 \\
11 \cdot 6 \pm 3 \cdot 0 \\
11 \cdot 0 \pm 0 \cdot 4\end{array}$ \\
\hline
\end{tabular}

repeatable on outpatients and the intensity of the stimulus may be varied simply by varying the duration of the exercise. This is important, as Buckler (1972) has shown that the response to exercise is modified by a number of factors including the physical fitness of the subject. But whatever the practical advantages, it is important to know how it compares in effectiveness with other stimulation tests. In order to do this the maximum values of serum growth hormone after stimulation by arginine, Bovril, insulin, and sleep have been extracted from a number of published series. These are summarized in Table II. The groups have been made as comparable as possible by including results only from normal children. Thus, in the present study only those children have been included whose heights fell above the third centile when allowance was made for midparental height, or whose growth rates from the age of 5 years were more than 5 $\mathrm{cm} /$ year, or whose bone ages were delayed by less than 1 year. In the study of Grant et al. (1970) the results cited after Bovril stimulation were from children who, though short, had growth hormone levels after insulin stimulation greater than 20 $\mathrm{mIU} / \mathrm{ml}$. In all other series the children were described as normally grown controls. Where results have been expressed in terms of the Wilhelmi standard, these have been multiplied by 2 to convert them to $\mathrm{mIU}$.

There is evidence that both random and peak growth hormone levels after insulin tend to be higher during adolescence than in earlier childhood (Hunter and Greenwood, 1964). The mean ages of the children included from the various studies, therefore, are shown. The age range of the children in this study clearly was less than that in the other groups, but the mean age was similar. A comparison of the proportion of children in each study in which the post-stimulation levels exceeded $20 \mathrm{mIU} / \mathrm{ml}$ indicates that exercise is as effective a stimulus as other agents. This, taken with the other advantages of the method, suggests that it has an important place in outpatient screening for growth hormone deficiency in short children.

K.A.L. was supported by a grant from the Royal Victoria Infirmary Scientific and Research Committee.

\section{REFERENCES}

Basu, A., Passmore, R., and Strong, J. A. (1960). The effect of exercise on the level of non-esterified fatty acids in the blood. Ouarterly fournal of Experimental Physiology, 45, 312.

Buckler, J. M. H. (1969). The effect of age, sex and exercise on the secretion of growth hormone. Clinical Science, 37, 765.

Buckler, J. M. H. (1972). Exercise as a screening test for growth hormone release. Acta Endocrinologica, 69, 219.

Frasier, S. D., Hilburn, J. M., and Matthews, N. L. (1967). The serum growth-hormone response to hypoglycaemia in dwarfism. Fournal of Pediatrics, 71, 625

Frohman, L. A., Aceto, T., and MacGillivray, M. H. (1967). Studies of growth hormone secretion in children; normal, hypopituitary and constitutionally delayed. Fournal of Clinical Endocrinology and Metabolism, 27, 1409.

Grant, D. B., Jackson, D., Raiti, S., and Clayton, B. E. (1970). Comparison of serum growth hormone levels after Bovril and insulin stimulation. Archives of Disease in Childhood, 45, 544.

Greenwood, F. C., Hunter, W. M. and Marrian, V. J. (1964). Growth-hormone levels in children and adolescents. British Medical fournal, 1, 25.

Hartog, M., Gaafar, M. A., Meisser, B., and Fraser, T. R. (1964). Immunoassay of serum growth hormone in acromegalic patients. British Medical fournal, 2, 1229.

Helge, H., Weber, B., and Quabbe, H. J. (1969). Growth-hormone release and venepuncture. Lancet, $1,204$.

Hunter, W. M., Fonseka, C. C., and Passmore, R. (1965). The role of growth hormone in the mobilization of fuel for muscular exercise. Quarterly fournal of Experimental Physiology, 50, 406.

Hunter, W. M., and Greenwood, F. C. (1964). A radio-immunoelectrophoretic assay for human growth hormone. Biochemical Fournal, 91, 43.

Hunter, W. M., Wolfsdorf, T., Farquar, J. W., and Rigal, W. M. (1967). Screening tests for growth-hormone deficiency in dwarfism. Lancet, 2, 1271.

Jackson, D., Grant, D. B., and Clayton, B. E. (1968). A simple oral test of growth-hormone secretion in children. Lancet, 2, 373. 
Kaplan, S. L., Abrams, C. A. L., Bell, J. J., Conte, F. A., and Grumbach, M. M. (1968). Growth and growth hormone. I. Changes in serum level of growth hormone following hypoglycaemia in 134 children with growth retardation. Pediatric Research, 2, 43.

Powell, G. F., Brasel, J. A., Raiti, S., and Blizzard, R. M. (1967) Emotional deprivation and growth retardation simulating idiopathic hypopituitarism. New England fournal of Medicine, 276, 1279.

Rabinowitz, D., and Merimee, T. J. (1968). Human Growth, p. 207. Ed. by D. B. Cheek. Lea and Febiger, Philadelphia.

Raiti, S. (1971). Assessment of endocrine function. In Recent Advances in Paediatrics, 4th ed., p. 271. Ed. by D. Gairdner and D. Hull. Churchill, London.

Root, A. W., Bongiovanni, A. M., and Eberlein, W. R. (1971). Diagnosis and management of growth retardation with special reference to the problem of hypopituitarism. Fournal of Pediatrics, 78, 737.

Root, A. W., Rosenfield, R. L., Bongiovanni, A. M., and Eberlein, W. R. (1967). The plasma growth hormone response to insulin-induced hypoglycaemia in children with retardation of growth. Pediatrics, 39, 844

Roth, J., Glick, S. M., Yalow, R. S., and Berson, S. A. (1963). Hypoglycaemia, a potent stimulus to secretion of growth hormone. Science, 140, 987.

Stimmler, L., and Brown, G. A. (1967). Growth hormone secretion provoked by insulin-induced hypoglycaemia in children of short stature. Archives of Disease in Childhood, 42, 232
Tanner, J. M., Goldstein, H., and Whitehouse, R. H. (1970). Standards for children's height at ages 2-9 years allowing for height of parents. Archives of Disease in Childhood, 45, 755.

Tanner, J. M., Whitehouse, R. H., and Healy, M. J. R. (1962). $A$ New System for Estimating Skeletal Maturity from the Hand and Wrist, with Standards Derived from a Study of 2,600 Healthy British Children. Centre International de L'Enfance, Paris.

Tanner, J. M., Whitehouse, R. H., Hughes, P. C. R., and Vince, F. P. (1971). Effect of human growth hormone treatment for one to seven years on growth of one hundred children, with growth hormone deficiency, low birth weight, inherited smallness, Turner's syndrome, and other complaints. Archives of Disease in Childhood, 46, 745.

Tanner, J. M., Whitehouse, R. H., and Takaishi, M. (1966). Standards from birth to maturity for height, weight, height velocity, and weight velocity; British children, 1965. Archives of Disease in Childhood, 41, 454.

Underwood, L. E., Azumi, K., Voina, S. J., and Van Wyk, J. J. (1971). Growth hormone levels during sleep in normal and growth hormone deficient children. Pediatrics, 48, 946.

Correspondence to Dr. J. M. Parkin, Department of Child Health, The Royal Victoria Infirmary, Queen Victoria Road, Newcastle upon Tyne NE1 4LP. 